\title{
A retrospective study of the clinical features of 50 consecutive cases diagnosed to have adenomyosis by histopathology in hysterectomy specimens in a tertiary centre
}

\author{
Sreelakshmy K. ${ }^{*}$, Rema V. Nair ${ }^{1}$, Rajmohan V. ${ }^{2}$
}

\begin{abstract}
${ }^{1}$ Department of Obstetrics and Gynecology, Sree Mookambika Institute of Medical Sciences, Tamil Nadu, India ${ }^{2}$ Research Co-ordinator, MES Medical College, Perinthalmanna, Kerala, India
\end{abstract}

Received: 16 May 2017

Accepted: 20 May 2017

\author{
*Correspondence: \\ Dr. Sreelakshmy K., \\ E-mail: sreelakshmy@yahoo.com
}

Copyright: (c) the author(s), publisher and licensee Medip Academy. This is an open-access article distributed under the terms of the Creative Commons Attribution Non-Commercial License, which permits unrestricted non-commercial use, distribution, and reproduction in any medium, provided the original work is properly cited.

\begin{abstract}
Background: Adenomyosis is characterised by the presence of ectopic endometrium, both glands and stroma deep in myometrium. Myometrial weakness caused by previous surgery or pregnancies, genetic factors, and tamoxifen use has been proposed as some aetiological factors.

Methods: Present study aims to study the clinical profile of patients who have histological evidence of adenomyosis in hysterectomy specimens. The records of consecutive patients who had undergone hysterectomy were analysed.

Results: The commonest age group affected is 41-50 years and menorrhagia is the predominant symptom. The preoperative diagnosis of adenomyosis remains poor at around $8 \%$.

Conclusions: The age of onset and clinical features of patients should serve as an index for suspecting adenomyosis.
\end{abstract}

Keywords: Adenomyosis, Dysmenorrhea, Hysterectomy, Menorrhagia

\section{INTRODUCTION}

Adenomyosis is characterized by presence of ectopic rests of endometrium both glands and stroma located deep in myometrium. ${ }^{1}$ Mechanisms that incite the deep myometrial invasions are myometrial weakness caused by prior pregnancies or surgery, decreased immunologic activity at endometrial-myometrial interface. ${ }^{1}$ Various other etiologies proposed are genetic factors, tamoxifen use and hyperprolactinemia. ${ }^{2,3}$ Alternate theory is that it is caused by metaplasia of pluripotent mullerian tissue. ${ }^{1}$ Preoperative diagnosis of adenomyosis remain poor and it is suggested that adenomyosis is solely an incidental finding at hysterectomy for benign disease and not the source of typical symptoms. ${ }^{4}$ The incidence of adenomyosis reported in literature in hysterectomy specimens is $50-70 \% .^{5}$ The specificity of preoperative diagnosis based on clinical picture is poor ranging from $2.6-26 \% .^{6}$ Average age of symptomatic women is usually older than 40 years. $^{7}$ Increasing parity, early menarche and short menstrual cycles may all be risk factors according to one study. ${ }^{7}$ The main symptoms are menorrhagia (40-60\%) dysmenorrhea (10-30\%) and metrorrhagia (10-12\%). ${ }^{8,9}$ Menorrhagia possibly results from increased and abnormal vascularisation of the endometrial lining ${ }^{1}$. Dysmenorrhea is thought to be due to increased prostaglandin production found in adenomyotic tissue. ${ }^{1}$ Parity and age are significant risk factors.

$90 \%$ cases are seen in parous women and $80 \%$ in women who are in their 40s and 50s. ${ }^{1}$ Adenomyosis is associated with pathologies that affect cytochrome p 450 aromatase expressions and higher oestrogen levels like leiomyoma, endometriosis and endometrial carcinoma. ${ }^{1}$ 


\section{METHODS}

The study was performed to evaluate the clinical profile of patients who have histopathological diagnosis of adenomyosis in hysterectomy specimens. This descriptive study was done in 50 patients in the Department of OBG at Sree Mookambika Institute of Medical Sciences during the period March 2014 to May 2015. 256 patients underwent hysterectomy during this period. 50 patients with features of adenomyosis on histopathological examination were included. The medical records of these patients were reviewed for information regarding age, parity, chief complaints and clinical diagnosis.

All patients who underwent hysterectomy both abdominal and vaginal, for any complaints were included in the study. Specimens with malignancies were excluded from the study group. Sections of uterus were stained with haematoxylin eosin stains and examined microscopically. Macroscopically, criteria for diagnosis of adenomyosis were enlarged uterus, a globular and or asymmetrical uterus with dense fasciculated myometrium with cystic areas of haemorrhage. ${ }^{10}$ Focal adenomyosis is defined by presence of adenomyoma or lesion localized to one uterine wall. ${ }^{10}$ In other cases, it is a diffuse pathology. Microscopically adenomyosis is diagnosed by presence of endometrial glands and stroma in the myometrium, more than one low power field away from the endomyometrial junction. ${ }^{11}$

\section{RESULTS}

A total of 256 hysterectomy specimens were analyzed during this period. Of these 256 patients, 50 patients had histopathological features of adenomyosis.

Table 1: Distribution of socio-demographic and clinical variables in adenomyosis patients.

\begin{tabular}{|c|c|c|}
\hline Variable & & $\%(\mathbf{N}=50)$ \\
\hline \multirow{4}{*}{ Age } & $41-50$ years & 40 \\
\hline & $51-60$ years & 38 \\
\hline & $61-70$ years & 18 \\
\hline & $>70$ years & 4 \\
\hline \multirow{3}{*}{ Symptoms } & Menorrhagia & 56 \\
\hline & Dysmenorrhea & 48 \\
\hline & Chronic pelvic pain & 40 \\
\hline \multirow{2}{*}{ Parity } & Uniparous & 22 \\
\hline & Multiparous & 78 \\
\hline \multirow{5}{*}{$\begin{array}{l}\text { Pre- } \\
\text { operative } \\
\text { diagnosis }\end{array}$} & $\begin{array}{l}\text { Abnormal uterine } \\
\text { bleeding }\end{array}$ & 32 \\
\hline & Fibroid & 24 \\
\hline & Uterovaginal prolapse & 24 \\
\hline & $\begin{array}{l}\text { Post-menopausal } \\
\text { bleeding }\end{array}$ & 14 \\
\hline & Adenomyosis & 8 \\
\hline
\end{tabular}

All patients were above 40 years. $40 \%$ were between the age group $41-50$ years and $38 \%$ in the age group 51- 60years, and $18 \%$ between $61-70$ years. Prevalence decreased to $4 \%$ in the age group more than 70 years. The predominant symptoms were menorrhagia in $56 \%$, dysmenorrhea in $48 \%$ followed by chronic pelvic pain in $40 \%$. Most patients were multiparous (78\%). Prevalence in uniparous was $22 \%$. The preoperative clinical diagnosis was abnormal uterine bleeding (AUB) in 32\%, fibroid in $24 \%$, uterovaginal prolapse in $22 \%$ and postmenopausal bleeding in $14 \%$ and adenomyosis in only $8 \%$ cases.

\section{DISCUSSION}

No prospective studies exist on the true prevalence of adenomyosis. In a study by Sheikh, the prevalence for adenomyosis was $20.6 \%{ }^{12}$ In another study done in India by Sharqillet al, the prevalence was $26 \% .{ }^{13}$ In present study the prevalence was $20 \%$ almost consistent with the previous ones. The commonest age group affected in SWANS study was $49.5 \pm 3.4 .^{4}$ In Sabins study largest numbers of patients were in the age group 41-50 years i.e. $70 \%$. Only $2 \%$ were age group 21-30 and 51-60 years. ${ }^{14}$ In present study all patients were above 40 years. Unlike the previous studies almost equal number of patients were affected in the age group 41-50 years (40\%) and 50-60 years $(38 \%)$. $70.5 \%$ had menorrhagia as the predominant symptom and $3.92 \%$ had post-menopausal bleeding in Khreisats study. ${ }^{15}$

In present study menorrhagia was the predominant symptom in $56 \%$ closely followed by dysmenorrhea in $48 \%$. Unlike previous studies our study group had $14 \%$ patients with postmenopausal bleeding which is much higher. Swans study group had prolapsed as the preoperative diagnosis in $10 \%$ cases. ${ }^{4}$ Present study group had prolapsed in $22 \%$ cases. In one study the maximum prevalence of adenomyosis is seen in patients with parity index $3.8 \pm 2.3 \mathrm{SD}$ and in another one it was $2.7 \pm 1.6 .^{16,17}$

In present study, consistent with previous authors majority $(82 \%)$ of patients had parity 3 or more. Thus, supporting the hypothesis that pregnancy allows adenomyotic foci to be included in myometrium due to invasive nature of trophoblast. The preoperative diagnosis of adenomyosis is poor ranging from 2.6-26\% in previous studies. ${ }^{9}$ In present study clinical diagnosis of adenomyosis was made in only $8 \%$ cases (Table 1 ).

\section{CONCLUSION}

Menorrhagia and dysmenorrhea are predominant symptoms of adenomyosis. The prevalence of adenomyosis in present study is $20 \%$ consistent with the previous studies. Commonest age group affected is between is 41-50 years but almost equal number of patients between to 51-60 years are also affected. It is diagnosed in patients with preoperative diagnosis of prolapse and post-menopausal bleeding. The preoperative diagnosis of adenomyosis remains poor at around $8 \%$. 
Funding: No funding sources

Conflict of interest: None declared

Ethical approval: The study was approved by the Institutional Ethics Committee

\section{REFERENCES}

1. Hoffman BL. Pelvic mass. Williams Gynaecology. $2^{\text {nd }}$ ed. Texas: MC Graw Hill; 2008:259-61.

2. Emge LA. Elusive adenomyosis of uterus. Its historical part and its present state of recognition. Am J Obstet Gynaecol. 1962;83:1541-63.

3. Cohen I, Beyth Y, Shapira J, Tepper R, Fishman A, Cordoba $\mathrm{M}$ et al. A high frequency of adenomyosis in post menopausal breast cancer patients who were treated with tamoxifen. Gynaecol Obstet Invest. 1997;44(3):200-5.

4. Weiss G, Maseelall P, Schott LL. Adenomyosis is a variant, not a disease? Evidence from hysterectomized menopausal women in the Study of Women's Health Across the Nation (SWAN). Fertil Steril. 2009;91(1):201-6.

5. Shrestha A, Shrestha R, Sedhai LB. Adenomyosis at hysterectomy: prevalence patient characteristics, clinical profile and histopathological findings. Kathmandu University Med J. 2012;37(10):53-56.

6. Reinhold C, Tafazolu F, Wang L. The imaging features of adenomyosis. Hum Reprod Update. 1998;4:37-49.

7. Rapkin AJ, Nathan L. Pelvic pain and dysmenorrhea in: Bereck. Berek and Novaks Gynaecology. $15^{\text {th }}$ ed. New Delhi:Wolters Kluwer Health India Pvt LTD; 2013:484-5.

8. Parazzini F, Vercellini P, Panazza S, Chatenoud L, Oldani S. The risk factors for adenomyosis. Hum Reprod. 1997;12:1275-9.

9. Vavilis D, Agorastos T, Tzafetas J. Adenomyosis at hysterectomy: its prevalence and its relationship to the operative findings and the reproductive and menstrual factors. Clin Exp Obstet Gynaecol. 1997;24:36-8.

10. Bazot M, Cortez A, Darai E, Rouger J, Chopier J, Antoine JM et al. Ultrasonography compared with magnetic resonance imaging for the diagnosis of adenomyosis: correlation with histopathology. Human Reprod. 2001;16(11):2427-33.

11. Rizvi C, Panday H. Histopathological Correlation of adenomyosis and leiomyoma in hysterectomy specimens as the cause of abnormal uterine bleeding in women in different age groups in Kumaon region a retrospective study. J Mid-life Health. 2013;4(1):27-30.

12. Shaikh H, Khan KS. Adenomyosis in Pakistani women. Four years of experience at the Aga Khan University Medical Centre, Karachi. J Clin Pathol. 1990;43:817-9.

13. Sharqill SK, Sharqill HK, Gupta M, Kaur S. A clinicopathological study of hysterectomy. J Indian Med Assoc. 2002;100:238-9.

14. Ranabhat SK, Shrestha R, Tiwari M, Sinha DP, Subedee LR. A retrospective histopathological study of hysterectomy with or without salpingoophorectomy specimens. JCMC. 2010;1(1):26-29.

15. Khreisat B, Al-Rawabdeh S, Duqoum W. Adenomyosis: the frequency of hysterectomy in the histopathological specimens at two Jordanian military hospitals. JRMS. 2011;18(2):76-79.

16. Levgur M, Abadi MA, Tucker A. Adenomyosis: symptoms, histology and pregnancy terminations. Obstet Gynaecol. 2000;95:688-91.

17. Panganamamula UR, Harmanli OH, Isik-Akbay EF, Grotegut CA, Dandolu V, Gaughan JP. Is prior uterine surgery arsk factor for adenomyosis? Obstet Gynaecol. 2004;104:1034-8.

Cite this article as: Sreelakshmy K, Nair RV, Rajmohan V. A retrospective study of the clinical features of 50 consecutive cases diagnosed to have adenomyosis by histopathology in hysterectomy specimens in a tertiary centre. Int J Reprod Contracept Obstet Gynecol 2017;6: 2791-3. 